\title{
Degradation of nitrate by enterobacteria during silage fermentation of grass
}

\author{
S. F. Spoelstra
}

Institute for Livestock Feeding and Nutrition Research (IVVO), P.O. Box 160, 8200 AD Leleystad, Netherlands

Received 13 October 1986; accepted 4 December 1986

Key words: nitrate degradation, enterobacteria, grass silage

\begin{abstract}
Enterobacteria were isolated from grass and from grass ensiled in laboratory silos. Strains isolated from grass belonged mainly to the Erwinia herbicola group. After ensiling the numbers of these bacteria diminished and Escherichia coli, Hafnia alvei and Klebsiella pneumoniae became the predominant bacteria in the respective experiments. Several strains, isolated either from grass or silage, were tested for their action on nitrate degradation by adding them to grass prior to ensiling. The isolates from grass did not affect nitrate degradation, whereas those from silage increased the rate of nitrate degradation and gave higher transient concentrations of nitrite and nitric oxide. The results indicate that there exists no direct relationship between the total number of enterobacteria on grass and its ensilability. And that in the experiments the number of enterobacteria on grass that developed after ensiling were two orders of magnitude lower than total number of enterobacteria originally present on the grass.
\end{abstract}

\section{Introduction}

Intensive grassland management with high fertilizer dressings can lead to crops for ensiling with $0.2-0.8 \%$ nitrate in the dry matter, and occasionally levels up to $3 \%$ may occur (Prins, 1983).

During the first days of silage fermentation nitrate is degraded with a transient accumulation of nitrite and nitric oxide, which are well documented inhibitors of clostridia (Ingram, 1976; Woods et al., 1981). It has been shown that the presence of nitrite and nitric oxide can also prevent clostridial growth during silage fermentation (Spoelstra, 1983a). The final reduction product of nitrate in silage is ammonium (Hellberg, 1967; Hein \& Weissbach, 1980; Ataku et al., 1982) or the gases nitric and nitrous oxide (Li \& Burris, 1960; Ataku et al., 1982; Spoelstra, 1985).

Nitrate reduction to gaseous products and ammonium are proton consuming processes. Thus in silage nitrate reduction inhibits clostridial growth by the formation 


\section{S. F. SPOELSTRA}

of nitrite and nitric oxide, but also counteracts acidification which eventually may lead to clostridial spoilage.

The processes involved in the degradation of nitrate during silage fermentation are not fully understood. Hein (1970) concluded from experiments with sterilized grass ensiled without and with addition of the epiphytic microbiota of grass that bacteria are responsible for the degradation of nitrate. But Li \& Burris (1960) found nitric oxide when germ-free grown soya-bean plants were ensiled, indicating that plant nitrate reductase plays a role as well.

It has been suggested that enterobacteria play an important role in nitrate reduction during silage fermentation (Gibson et al., 1958; Bousset-Fatianoff et al., 1971). They reduce nitrate to nitrite with often ammonium being the most reduced end-product (Yordy \& Ruoff, 1981). In addition, they are capable of reducing nitrite to nitrous oxide (Bleakley \& Tiedje, 1982).

On grass, enterobacteria present a minor part of the epiphytic microbiota (Goodfellow et al., 1976); during wilting their numbers increase (Weise, 1969). A rapid increase occurs during the first days of ensiling, however with increasing acidity the numbers decline and in well-preserved silages they are absent (Gibson et al., 1958; 1961).

The present investigation was undertaken to evaluate the role of enterobacteria in the degradation of nitrate during silage fermentation.

\section{Materials and methods}

\section{Experimental}

Enterobacteria during wilting. The number of enterobacteria on the grass during wilting was followed by daily sampling a plot of $12 \mathrm{~m} \times 6 \mathrm{~m}$ with mainly perennial rye grass. The plots were part of the experiment fields of IVVO and underwent routine farm practice for silage making (i.e. mowing with a disc mower and tedding once per day). The plots were sampled by combining 10-15 grab-samples, which were sub-sampled by coring (diameter $40 \mathrm{~mm}$ ).

\section{Ensiling}

Unwilted or wilted pre-ear emergent perennial rye grass was chopped (chop length 20-40 mm) and ensiled without and with addition of a bacterial strain. The strains used were isolated either from grass or from silage and belonged to the Enterobacteriaceae. The strains added were pre-grown overnight in peptone-yeast extractglucose broth, harvested by centrifugation and resuspended in quarter-strength Ringer solution. The required amount of bacterial suspension was sprayed on the grass which was continuously mixed in a 150-1 concrete mixer. The control was sprayed with quarter-strength Ringer solution only. Of each treatment $2700 \mathrm{~g}$ of grass was ensiled in the IVVO-laboratory silo. Experimental details of the laboratory silo and sampling procedures have been described previously (Spoelstra, 1983b).

The silages were sampled periodically and analysed for nitrate, nitrite, nitric 
oxide, nitrous oxide, $\mathrm{pH}$ value, lactic acid, ethanol, volatile fatty acids and number of enterobacteria.

\section{Short-term incubations}

Strains of enterobacteria isolated from grass or silage were tested for their action on nitrate during silage fermentation. Bacterial suspensions were prepared in quarter-strength Ringer solution and sprayed on the grass to give an inoculation of $10^{7}$ $10^{8} / \mathrm{g}$. In a $300-\mathrm{ml}$ flask $100 \mathrm{~g}$ of grass were ensiled for 20 hours at $30^{\circ} \mathrm{C}$, and subsequently analysed for $\mathrm{pH}$ value and nitrate and nitrite content.

\section{Chemical analyses}

Chemical analyses were performed as described before (Spoelstra, 1983a). This with exception of the estimation of nitrate and nitrite in silage extract, which were analysed on an autoanalyser as described for rumen fluid by Kemp et al. (1977).

\section{Microbiological procedures}

Extracts of grass and silage were prepared by treating $30 \mathrm{~g}$ to which $270 \mathrm{~g}$ of distilled water had been added for $5 \mathrm{~min}$ in a Stomacher (Seward Laboratory, London). From the extract decimal dilution series was prepared in quarter-strength Ringer solution. Enterobacteria were enumerated on pour plates of violet red bile glucose agar (VRB; Oxoid). The colonies were counted after incubation for 2 days at $30^{\circ} \mathrm{C}$. Per sample two dilution series were prepared and petri dishes inoculated in duplicate.

The most probable number of nitrate-reducing bacteria was assessed by incubating per dilution three tubes with trypticase nitrate broth (BBL). After 2 days at $30^{\circ} \mathrm{C}$ the tubes were tested for nitrite. For isolating bacteria single colonies were randomly picked from VRB and streaked to purity on PYG agar $\left(\mathrm{g} \mathrm{l}^{-1}:\right.$ peptone 5 , yeast extract 2, glucose $1, \mathrm{Na}_{2} \mathrm{HPO}_{4} 2$, agar 12).

Strains were characterized by the API 20E system (API system, Montalieux, Vercieu, France) following the manufacturer's guidelines with the Analytical Profile Index. The strips were incubated at $30^{\circ} \mathrm{C}$.

\section{Results}

\section{Enterobacteria on grass}

In 13 experiments, varying in wilting period from 2 to 8 days, the development of the number of enterobacteria was followed. At mowing the average count amounted to $6.38 \pm 0.51$ (range 5.38-7.13) logarithmic units per gram dry matter (lu per $\mathrm{g}$ $\mathrm{dm}$ ). During the wilting period the numbers of enterobacteria increased on average with 0.27 lu per $\mathrm{g} \mathrm{dm}$ per day (percentage of variance accounted for was 68 ).

No influence of the dry matter content (ranging from 130 to $590 \mathrm{~g} / \mathrm{kg}$ ) on the development of enterobacteria during wilting was observed.

Of 5 randomly chosen samples of wilted grass the counts of enterobacteria on VRB were compared with the most probable number of bacteria that reduce nitrate to nitrite. The counts did not differ significantly (t-test). In addition 71 colo- 
S. F. SPOELSTRA

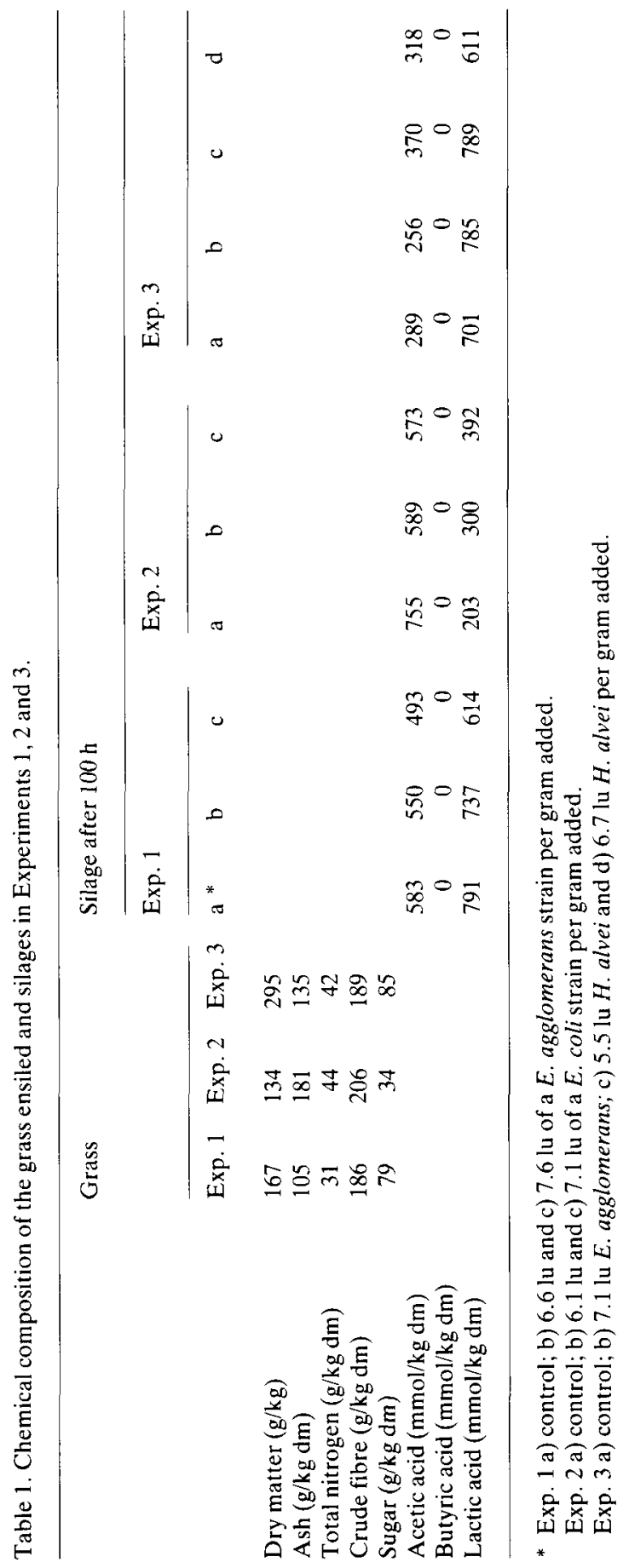


DEGRADATION OF NITRATE BY ENTEROBACTERIA
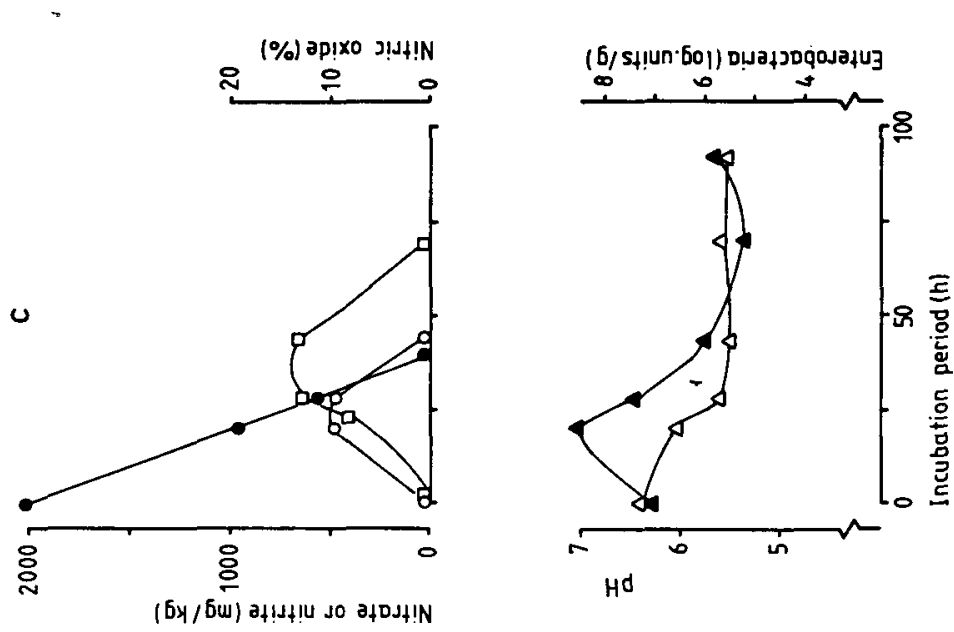

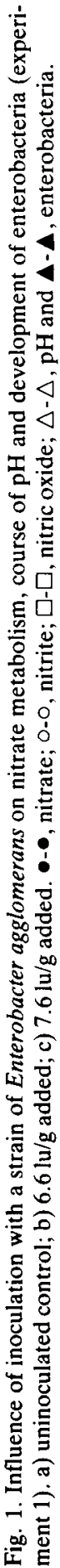

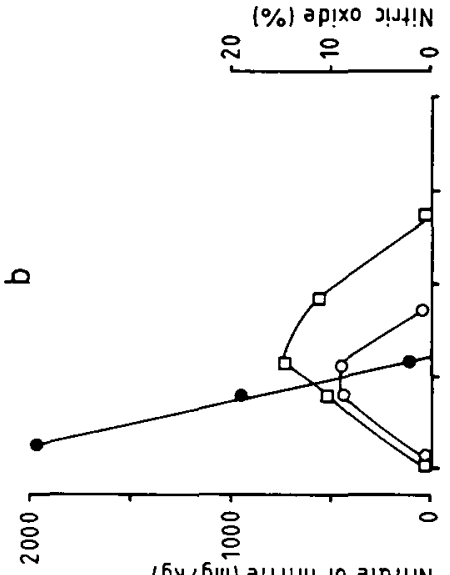

$\left(\sigma_{y} / 6 w\right)$ at!J\}!U J०
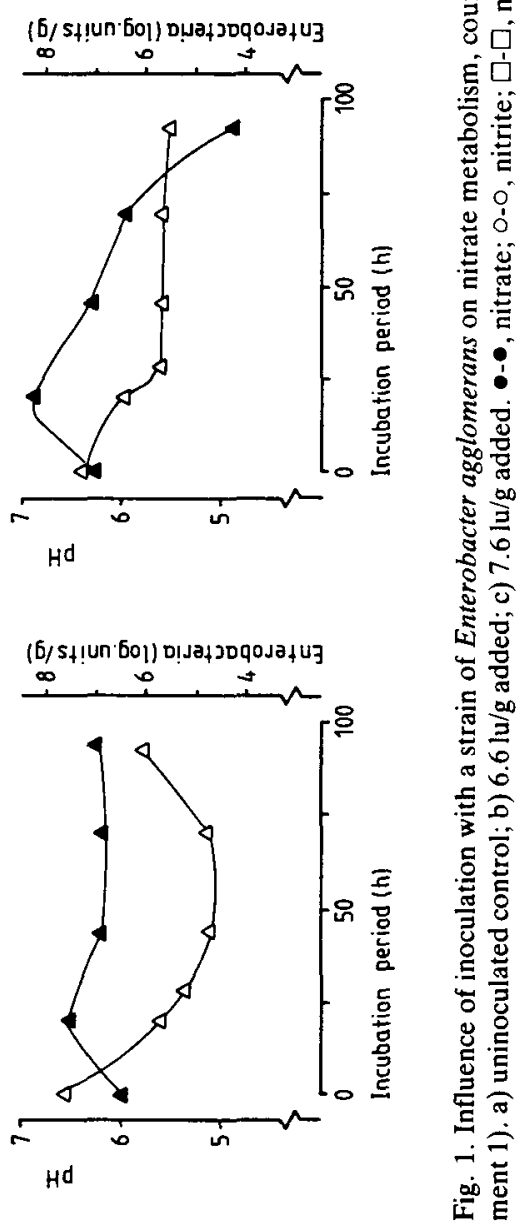

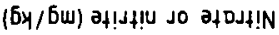


nies were randomly picked from VRB agar and transferred to nitrate-broth. Sixtyseven colonies ( $94 \%$ ) showed formation of nitrite.

Eighty-one isolates from direct cut and prewilted grass were characterised, 40 belonged to the species Enterobacter agglomerans, 31 strains were identified as Enterobacter species, 9 strains could not be readily identified.

\section{Effect of addition of enterobacteria to grass on silage fermentation}

In three experiments grass was inoculated with enterobacteria and ensiled. The chemical compositions of the grass and the silages 100 hours after the start of ensiling are given in Table 1 . The grass in alle three experiments had crude fibre contents of about $200 \mathrm{~g} / \mathrm{kg} \mathrm{dm}$, high nitrogen contents and low sugar levels. For Experiments 1 and 2, with unwilted grass, the initial lactic acid fermentation suggested in Table 1 was followed by a butyric acid fermentation. Ensilage of the wilted grass in Experiment 3 resulted in silages without butyric acid.

\section{Experiment 1}

In this experiment a strain isolated from wilted grass was sprayed on the grass to give 6.6 and 7.6 lu per gram, for the low and high level, respectively. This in addition to 6.6 lu per $g$ enterobacteria that were naturally present. The strain used was identified as E. agglomerans, indole-, saccharose + and had a yellow pigment (API code 1005172).

The results of this experiment are presented in Fig. 1. Nitrate degradation and accumulation of nitrite and nitric oxide were similar for the inoculated silages and the control silage. Reduction of nitrate started at the beginning of ensiling. All nitrate had disappeared from the silages after 100 hours. The course of the $\mathrm{pH}$ value was similar for all silages. It dropped to 4.5 within 40 hours and increased slightly again after this period. On 80 hours after ensiling increasing amounts of hydrogen gas was present in the atmosphere of the silo, indicating clostridial fermentation. Finally, 650 hours after the start of ensiling the $\mathrm{pH}$ value had risen over 6.0 and the silages contained about $900 \mathrm{mmol}$ butyric acid per kg dry matter.

The number of enterobacteria showed a maximum at about 20 hours and decreased slowly afterwards.

Twelve strains of enterobacteria were isolated from a sample taken from the control silage 70 hours after ensiling. All strains were identified as Escherichia coli.

\section{Experiment 2}

In this experiment grass was sprayed with a strain identified as $E$. coli (API code 5144572), which had been isolated from the control silage in Experiment 1. In addition to the $6.5 \mathrm{lu} / \mathrm{g}$ of enterobacteria naturally present, $6.1 \mathrm{lu} / \mathrm{g}$ and $7.1 \mathrm{lu} / \mathrm{g}$ were added for the low and high level of addition, respectively.

Addition of this strain increased the speed of nitrate degradation with concomittantly higher levels of nitrite and nitric oxide than the control (Fig. 2). The $\mathrm{pH}$ values in the experimental silages remained higher during the first phase of the fermentation than in the control silage. All three silages were eventually spoiled by butyric acid fermentation, which started, as indicated by production of hydrogen, 
DEGRADATION OF NITRATE BY ENTEROBACTERIA

0

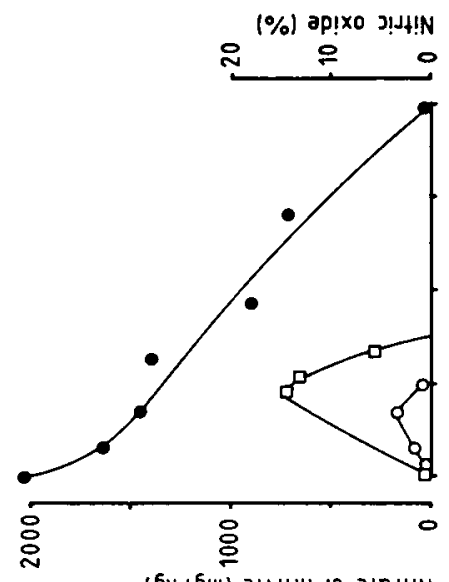

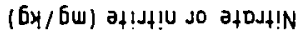

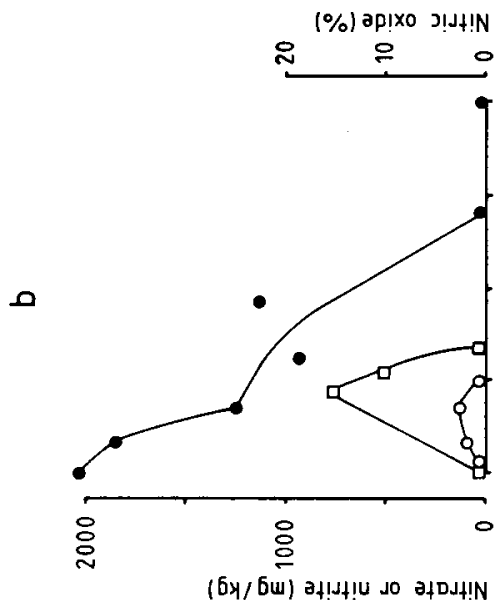

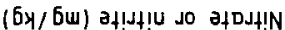

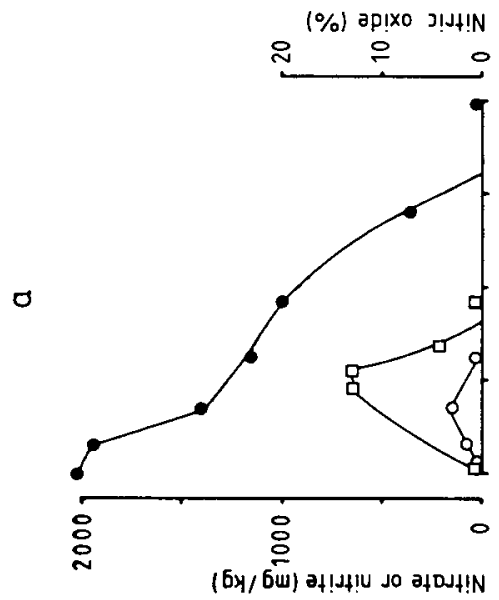

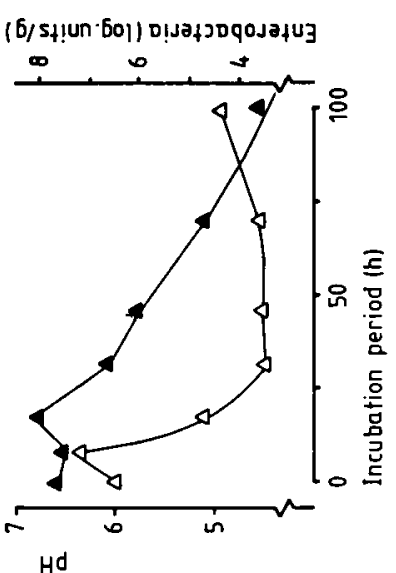

$($ L/2hiun . Do) Dijatzogojatuz

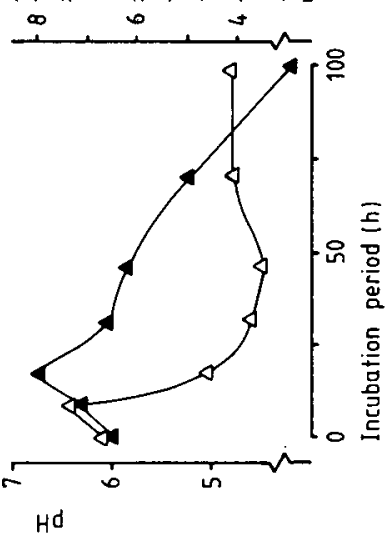

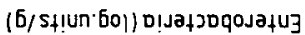

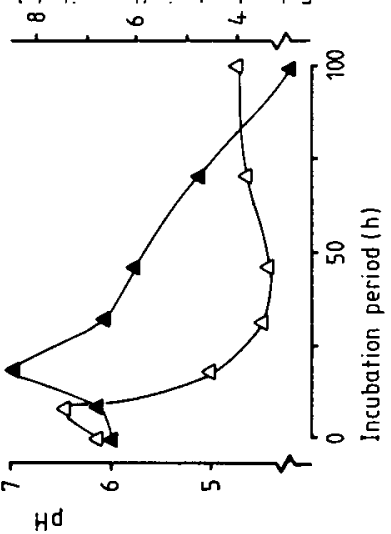

两

तิ

롤

ֻ.

焉

:

造

I

प्ष

范

氚

8.

हैं

뭉

ह

品

뭉

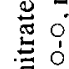

ह

ธิ

亏.

s!

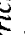

过

乩

on

$\Xi \Xi$

灵

mi

5

ธำ

栗

응

.

o

Ð

总

i

拄要 

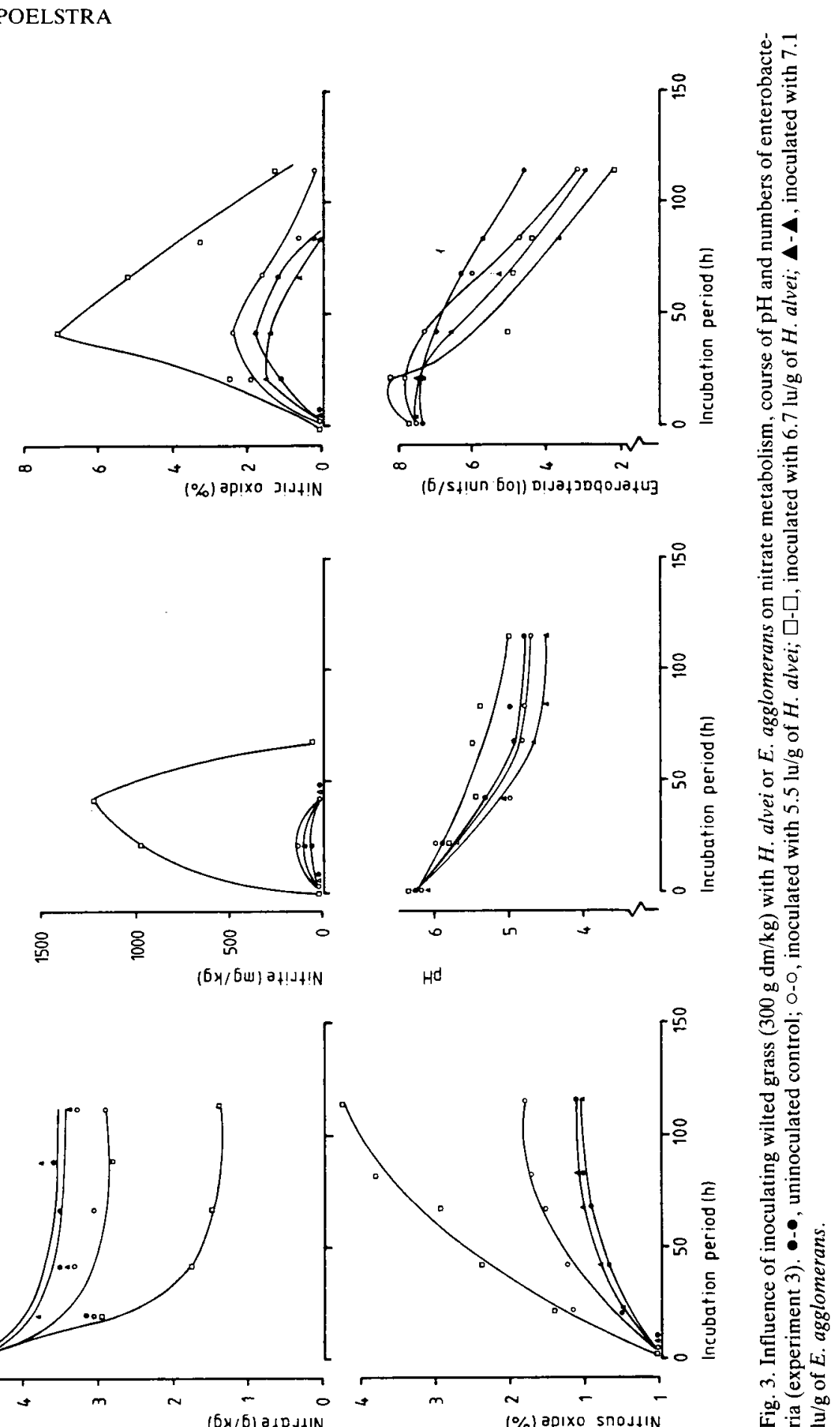

$H^{d}$
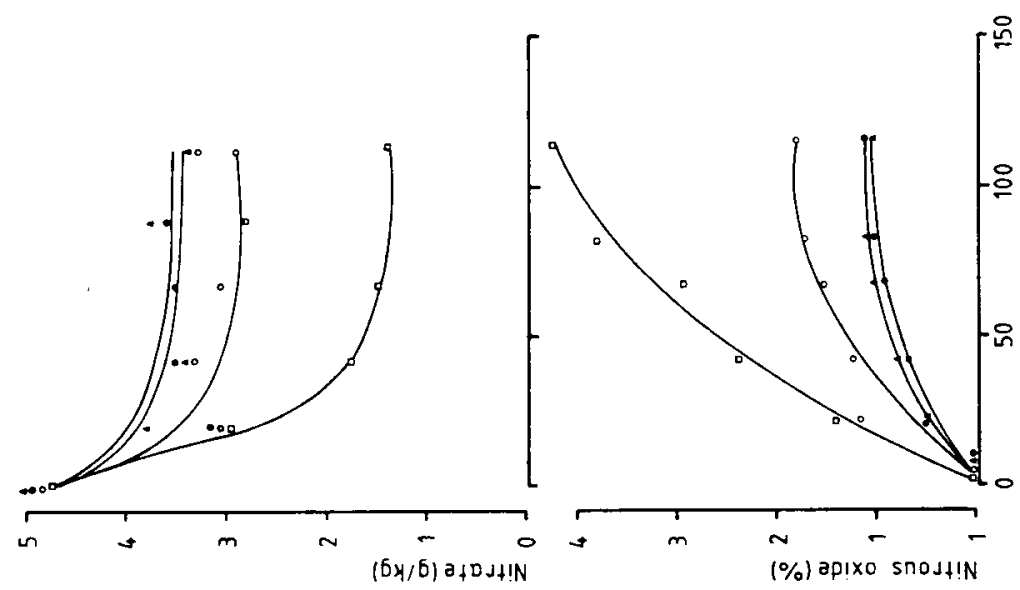

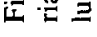

Netherlands Journal of Agricultural Science 35 (1987) 
about 70 hours after the beginning of ensiling. The $\mathrm{pH}$ values after 500 hours were 6.5 or higher and the butyric acid contents amounted to about $900 \mathrm{mmol} / \mathrm{kg}$ dry matter in all three silages.

From the control silage enterobacteria were isolated from samples taken 20,92 , 119 and 164 hours after ensiling. Of the 17 strains obtained from the first sample 8 were identified as E. agglomerans, 6 as Hafnia alvei, 1 as Citrobacter freundii and 1 as $E$. coli. One strain could not be identified. The 26 isolates obtained from the other samples were attributed to the following species: E. agglomerans $1, H$. alvei 6, C. freundii 2, Proteus morganii 4, and E. coli 12 . One strain could not be placed taxonomically.

\section{Experiment 3}

Wilted grass was inoculated with either 5.5 or $6.7 \mathrm{lu} / \mathrm{g}$ of a Hafnia alvei strain (API code 4105112) which had been isolated from the silage in Experiment 2 or with 7.1 lu/g of E. agglomerans (API code 1005573) isolated from grass. This in addition to the 7.4 lu epiphytic enterobacteria per gram already present. Inoculation with $E$. agglomerans did not influence any of the parameters measured during silage fermentation (Fig. 3). This in contrast to $H$. alvei which at the low level of inoculation gave a small increase in the rate of nitrate degradation and a moderate increase of the maximum nitrite, nitric oxide and nitrous oxide levels. These effects were much more pronounced with the high level of inoculation furthermore a retarded $\mathrm{pH}$ drop was observed in this case. Twenty-one hours after the start of ensiling the number of enterobacteria had risen to $8.2 \mathrm{lu} / \mathrm{g}$, while after $200 \mathrm{~h}$ their number had fallen below $10 / \mathrm{g}$ in the silages tested. Thirty strains, all identified as Enterobacter spp., were isolated from the grass before ensiling. After 1, 2 and 4 days, respectively, 17 out of 39, 12 out of 30 and none out of 28 isolates were identified as such. The dominating species in this experiment was Klebsiella pneumoniae (3, 10 and 11 strains after 1,2 and 4 days, respectively). The other strains were identified Enterobacter cloacae (6 strains), Escherichia coli (4), Hafnia alvei (3), Klebsiella oxytoca (2) and Citrobacter freundii (1). Twelve strains could not be identified.

Table 2. Nitrate degradation upon inoculation of grass with different strains of enterobacteria (shortterm experiments).

\begin{tabular}{llc}
\hline Bacterium added & $\begin{array}{l}\text { Number of strains } \\
\text { tested }\end{array}$ & $\begin{array}{l}\% \text { Nitrate degraded } \\
\text { after } 20 \mathrm{~h}^{*}\end{array}$ \\
None & & $10-25$ \\
Enterobacter agglomerans & 7 & $10-30$ \\
Escherichia coli & 7 & $85-95$ \\
Hafnia alvei & 2 & 100 \\
Citrobacter freundii & 2 & $85-90$ \\
Proteus morganii & 1 & 93 \\
\hline
\end{tabular}

* Percentage of nitrate present in the original grass; range of results. 
In the silages inoculated with $H$. alvei this bacterium clearly dominated (8 out 10 and 10 out of 10 isolates for the low and high inoculation level respectively in samples taken 2 days after ensiling). From the silage inoculated with E. agglomerans 1 from the 11 strains isolated 2 days after.ensiling could be attributed to this species.

\section{Short-term incubations}

In total 19 strains were tested in 20 hours trials for their action on nitrate during silage fermentation (Table 2). Strains identified as E. agglomerans did not affect nitrate degradation and silage fermentation. Strains identified as E. coli, H. alvei, C. freundii and $P$. morganii showed increased nitrate degradation when added to grass, resulting in increased levels of nitrite and $\mathrm{pH}$ values after 20 hours in comparison to control trials.

\section{Discussion}

Nearly all colonies developing on VRB could reduce nitrate. Colony counts on VRB and the most probable number of nitrate-reducing bacteria gave similar results. From these observations it is concluded that colony counts on VRB give a good estimate of the number of bacteria on grass that are able to reduce nitrate.

The numbers of enterobacteria on grass found here agreed well with those reported by Weise (1969). During wilting enterobacteria increased. This was also reported by Weise (1969) and Beck (1965) noted that grass wilted under wet weather conditions has an elevated count of enterobacteria.

Most organisms isolated from grass were identified as E. agglomerans by the API system. This system has primarily been developed for the identification of clinical isolates. From the origin of the samples it seems more appropriate to use the synonym Erwinia herbicola (Starr, 1981), and it is assumed that all the isolates from grass belong to the E. Herbicola group, which has been found to be the predominant group of enterobacteria present on grass (Goodfellow et al., 1975).

Erwinia herbicola made up for $47 \%$ of the strains isolated 20 hours after the beginning of ensiling (Exp. 2). From the samples taken after 92 hours and later only one strain $(3 \%)$ was identified as $E$. herbicola. The results suggest that shortly after ensiling $H$. alvei developed and that after a few days $E$. coli dominated the enterobacteria in silage. In experiment 3 Klebsiella pneumoniae became the predominant enterobacterium. In literature enterobacteria proliferating in silage were characterized as 'Linked to the klebsiella group' (Gibson et al., 1958; 1961), Hafnia spp. (Gouet, 1966) and E. coli (Barnett, 1953), which accords with the identification of the organisms isolated in this study.

Addition of $E$. herbicola strains isolated from grass and silage before ensiling (Exp. 1 and 3 and short-term incubations) did not influence nitrate metabolism in silage. Upon ensiling, this group of organisms died off rapidly and did apparently not influence silage fermentation when added tot the grass before ensiling (Exp. 1 and 3). This is contrast to E. coli, Hafnia alvei and some other strains isolated from silage (Exp. 2 and 3 and short-term experiments) which degraded nitrate during silage fermentation and therewith could influence silage quality. This is most appa- 
rent from the increased $\mathrm{pH}$ values, which probably are the result of two effects. Degradation of nitrate to $\mathrm{NO}_{\mathrm{x}}$ gases and ammonium binds one and two protons respectively. Furthermore as a result of nitrate respiration there could be a shift in composition of fermentation products from lactic to the weaker acetic acid (Yamomoto \& Ishimoto, 1981), which also means an increase in buffering capacity.

The total number of enterobacteria during wilting increased, as has been found before (Beck, 1965; Weise, 1969). However, the results show that the predominant enterobacteria on grass influenced neither nitrate degradation nor any other parameter observed during silage fermentation. This implies that there is not a direct relationship between the total number of enterobacteria on grass and its ensilability. Results of experiment 3 showed that inoculation with $5.5 \mathrm{lu} / \mathrm{g}$ of $H$. alvei had a moderate influence on the parameters studied. This could indicate that the level of enterobacteria on the grass active after ensiling was in this experiment at this order of magnitude and probably somewhat lower, whereas the total number of enterobacteria on the grass in this experiment amounted to $7.4 \mathrm{lu} / \mathrm{g}$. In Experiment 2 inoculation with 6.1 or $7.1 \mathrm{lu} / \mathrm{g}$ of $E$. coli, in addition to the $6.5 \mathrm{lu} / \mathrm{g}$ naturally present, resulted in a similar major effect on nitrate catabolism. This indicates that the level of enterobacteria on the grass active after ensiling was considerably below $6.1 \mathrm{lu} / \mathrm{g}$.

The results of these experiments suggest that the level of enterobacteria that influence silage fermentation could be about 2 orders of magnitude lower than the total number of enterobacteria on the grass.

The total number of enterobacteria on grass increased during wilting. Whether the same is true for the minority of enterobacteria that is active after ensiling remains unsure.

\section{References}

Ataku, K., M. Honiguchi \& T. Matsumoto., 1982. The ralationship between silage quality and ${ }^{15} \mathrm{~N}-\mathrm{ni}-$ trate reduction during ensilage. In: Proceedings of the 14th International Grassland Congress (Kentucky) pp. 663-665.

Barnett, A. J. G., 1953. The reduction of nitrate in mixtures of minced grass and water. Journal of the Science of Food and Agriculture 4: 92-96.

Beck, T., 1965. Untersuchungen über die Okologie und Physiologie der Gärfuttermikroflora. Landwirtschaftliche Forschung (Sonderheft) 19:243-251.

Bleakley, B. H. \& J. M. Tiedje, 1982. Nitrous oxide production by organisms other than nitrifiers or denitrifiers. Applied and Environmental Microbiology 44: 1342-1348.

Bousset-Fatianoff, N., P. Gouet, J. Bousset, \& M. Contrepois, 1971. Recherche des nitrates dans les fourrages et les ensilages II. Origine du catabolisme des nitrates dans les ensilages et leur intersités de leur dégradation en fonction du traitement technologiques, Annales de Biologie Animale, Biochimie, Biophysique 11: 715-723.

Gibson, T., A. C. Stirling, R. M. Keddie, \& R. F. Rosenberger, 1958, Bacteriological changes in silage made at controlled temperatures. Journal of General Microbiology 19: 112-119.

Gibson, T., A. C. Stirling, R. M. Keddie \& R. F. Rosenberger, 1961. Bacteriological changes in silages as affected by laceration of the fresh grass. Journal of General Microbiology 24: 60-70.

Goodfellow, M., B. Austin \& D. Dawson, 1976. Classification and identification of phylloplane bacteria using numerical taxonomy. In: C. H. Dickinson \& T. F. Preece (Eds.), Microbiology of aerial plant surfaces, pp. 275-292. London, Academic Press.

Gouet P., 1966. The evolution of Gram-negative microflora in direct harvested and wilted alfalfa silages. Proceedings of the 10th International Grassland Congress (Helsinki), p. 533-536. 


\section{S. F. SPOELSTRA}

Hein, E., 1970. Die Beeinflussung des Gärungsverlaufes bei der Grünfuttersiliering durch den Nitratgehalt des Ausgangsmaterials. Dissertation, Rostock, GDR, 118 pp.

Hein, E. \& F. Weissbach, 1980. Decomposition processes and effects of nitrate in ensiling green forages. In: Proceedings of the 13th International Grassland Congress (Leipzig), p. 1323-1325.

Hellberg, A., 1967. Einfluss der N-Düngung und des Schnittzeitpunktes auf die Silierfähigkeit des Grünfutters. Das Wirtschaftseigne Futter 13: 111-129.

Ingram, M., 1976. The microbiological role of nitrite in meat products. In: F. A. Skinner \& J. G. Carr (Eds.), Microbiology in agriculture, fisheries and foods, p. 1-18. Society of Applied Bacteriology Symposium series 4 . London, Academic Press.

Kemp, A., J. H. Geurink, R. T. Haalstra \& A. Malestein, 1977. Nitrate poisoning in cattle. 2. Changes in nitrite in rumen fluid and methemoglobin formation in blood after high nitrate intake. Netherlands Journal of Agricultural Science 25: 51-62.

Li Chuang Wang \& R. H. Burris, 1960. Mass spectrometric study of nitrogenous gases produced by silage. Agricultural and Food Chemistry 8: 239-242.

Prins, W. H., 1983. Effect of a wide range of nitrogen applications on herbage nitrate content in longterm fertilizer trials on all-grass swards. Fertilizer Research 4: 101-113.

Starr, M. P., 1981. The genus Erwinia. In: M. P. Starr, M. Stolp, H. G. Trüper, A. Balows \& H. G. Schlegel (Eds.), The prokaryotes, p. 1260-1271. Berlin, Springer Verlag.

Spoelstra, S. F., 1983a. Inhibition of clostridial growth by nitrate during the early phase of silage fermentation. Journal of the Science of Food and Agriculture 34: 145-152.

Spoelstra, S. F., 1983b. A laboratory silo permitting repeated sampling. Netherlands Journal of Agricultural Science 31: 89-92.

Spoelstra, S. F., 1985. Nitrate in silage. Grass and Forage Science 40: 1-11.

Weise, F., 1969. Einfluss des epiphytischen Keimbesatzes auf den Gärverlauf. In: Proceedings of the 3rd meeting of the European Grassland Federation (Braunschweig), p. 221-227.

Woods, L. F. J., J. M. Wood \& P. A. Gibbs, 1981. The involvement of nitric oxide in the inhibition of the phosphoroclastic system in Clostridium sporogenes by sodium nitrite. Journal of General Microbiology 125: 339-406.

Yamamoto, I. \& M. Ishimoto, 1981. Oxidation of lactate in comparison with that of glucose in nitrate respiration of Escherichia coli. Journal of General and Applied Microbiology 27: 11-20.

Yordy, D. M. \& K. L. Ruoff, 1981. Dissimilatory nitrate reduction to ammonia. In: C. C. Delwiche (Ed.), Denitrification, nitrification and atmospheric nitrous oxide, p. 171-190. New York, John Wiley. 